Article

\title{
Consequences of Transition Treatments on Fertility and Associated Metabolic Status for Dairy Cows in Early Lactation
}

\author{
Junnan Ma ${ }^{1}\left(\right.$, Renny J. van Hoeij ${ }^{1}$, Rupert M. Bruckmaier ${ }^{2}{ }^{\circledR}$, Akke Kok ${ }^{1}{ }^{\mathbb{D}}$, \\ Theo J. G. M. Lam ${ }^{3,4}$, Bas Kemp ${ }^{1}(\mathbb{D})$ and Ariette T. M. van Knegsel ${ }^{1, *(D)}$ \\ 1 Department of Animal Sciences, Adaptation Physiology Group, Wageningen University, P.O. Box 338, \\ 6700 AH Wageningen, The Netherlands; junnan.ma@wur.nl (J.M.); rennyvanhoeij@gmail.com (R.J.v.H.); \\ akke.kok@wur.nl (A.K.); bas.kemp@wur.nl (B.K.) \\ 2 Veterinary Physiology, Vetsuisse Faculty, University of Bern, CH-3001 Bern, Switzerland; \\ rupert.bruckmaier@vetsuisse.unibe.ch \\ 3 Department Farm Animal Health, Utrecht University, P.O. Box 80151, 3508 TD Utrecht, The Netherlands; \\ T.Lam@gddiergezondheid.nl \\ 4 GD Animal Health, P.O. Box 9, 7400 AA Deventer, The Netherlands \\ * Correspondence: ariette.vanknegsel@wur.nl
}

Received: 29 May 2020; Accepted: 22 June 2020; Published: 25 June 2020

Simple Summary: Shortening or omitting the dry period improves energy balance and metabolic status, but reduces milk production and increases the risk of body fattening of cows in the subsequent lactation. Reducing the postpartum dietary energy level in order to match the lower milk yield after 0-d dry period could prevent body fattening. Earlier, reducing postpartum dietary energy level for cows after 0-d dry period reduced days open in the subsequent lactation, which may indicate improved underlying fertility. This study investigated effects of reducing dietary energy level from week 4 postpartum onwards for cows after 0 -d dry period on fertility variables and associated metabolic status. Reducing the postpartum dietary energy level in cows with 0-d dry period reduced the interval from calving to onset of luteal activity in cows of parity $\geq 3$, compared with a standard dietary energy level or a 30-d dry period. Fewer days open was related to fewer services per conception, fewer days to onset of luteal activity, higher percentage of ovarian cycles of normal length (18-24 d), and improved energy balance in weeks 1-7 of lactation. In conclusion, reducing a postpartum dietary energy level to match lower milk yield after 0-d dry period improved fertility in cows of parity $\geq 3$, but not in cows of parity 2 .

Abstract: This study aimed to (1) investigate effects of reducing postpartum dietary energy level for cows after a 0 -d dry period (DP) on resumption of ovarian cyclicity and reproductive performance, (2) relate days open with other reproductive measures, and (3) relate onset of luteal activity (OLA) and days open with metabolic status in early lactation. Holstein-Friesian dairy cows were randomly assigned to 1 of 3 transition treatments: no DP and low postpartum dietary energy level from 22 days in milk( DIM )onwards (0-d DP (LOW)) $(n=42)$, no DP and standard postpartum dietary energy level (0-d DP (STD)) $(n=43)$, and a short DP and standard postpartum dietary energy level (30-d DP (STD)) $(n=43)$. Milk progesterone concentration was determined three times per week until 100 DIM. Plasma metabolite and hormone concentrations were measured weekly until week 7 postpartum. Reducing postpartum dietary energy level in older cows (parity $\geq 3$ ) after no DP and 22 DIM did not affect milk production but prevented a positive energy balance and shortened the interval from calving to OLA. In addition, services per pregnancy and days open were reduced in cows of parity $\geq 3$ on 0-d DP (LOW), compared with cows of parity $\geq 3$ with 0-d DP (STD), but not in cows of parity 2 . 
Keywords: dry period length; dietary energy level; ovarian activity; metabolic status

\section{Introduction}

Shortening or omitting the dry period (DP) length were reported to improve fertility, indicated by an earlier onset of first ovulation postpartum [1] and overall improved resumption of ovarian cyclicity [1-3]. Consistent with the concept that earlier first ovulation may improve reproductive performance, omitting the DP was associated with an increased percentage of cows pregnant to first artificial insemination (AI) $(55 \%, 26 \%$, and $20 \%$ for $0-d, 28-d$, and $56-d$ DP, respectively) and decreased days open $(94,121$, and $145 \mathrm{~d}$ for 0-d, 28-d, and 56-d DP, respectively) [4]. Moreover, in another study, first-service pregnancy rate was greater in multiparous cows with a 35-d DP compared with cows with a longer DP [5]. In some other studies, however, no effects of DP length on pregnancy rate and days open were found after a short DP [6,7] or an omitted DP [7]. In all these studies, a postpartum dietary energy level was not adjusted to the lower milk yield for cows with 0-d DP or a short DP, compared with cows with a conventional DP.

Unfavorable consequences of omitting the DP can be a reduction in milk yield and fattening of cows in the subsequent lactation [8]. Adjusting dietary energy level in early lactation could be a strategy to limit these negative consequences [9]. Earlier, we reported that reducing postpartum dietary energy level for cows with 0-d DP did not affect milk yield or milk composition, but resulted in a less positive energy balance (EB) and less body weight gain in the subsequent lactation, compared with cows fed postpartum a standard energy level after no DP [9]. Moreover, cows with no DP and low postpartum dietary energy level (0-d DP (LOW)) had less days open than cows with no or a short DP and standard postpartum dietary energy level (0-d DP (STD) or 30-d DP (STD)). Days open is influenced by both the interval between calving to insemination and the success of an insemination [10]. Resumption of ovarian cyclicity, which is a combined trait consisting of onset of ovarian activity and regularity of the ovarian cycles, is related with the timing of the first insemination and success of insemination [11]. It can be hypothesized that the reduced days open for cows with 0-d DP (LOW), as we saw earlier [9], is related with an improved resumption of ovarian cyclicity or an increased conception rate after insemination or both.

Improvement in reproductive performance related with a reduction in DP length can be associated with an improved EB and metabolic status [1,3,4]. Concentrations of plasma glucose, IGF-I, and insulin were greater, but milk yield, plasma concentrations of non-esterified fatty acids (NEFA), and liver tri-acyl glycerides (TAG) were lower for cows after a 0-d DP than for cows after a 30-d or 60-d DP [3]. These endocrine and metabolic factors were associated with ovarian activity postpartum [12-14]. Elevated concentrations of NEFA and $\beta$-hydroxybutyrate (BHB) in plasma reduced oocyte and blastocyst quality in vitro $[15,16]$ and were associated with a later onset of luteal activity (OLA) in vivo $[3,17]$. In particular, IGF-1 and insulin are key factors for the ovarian function because they both stimulate estradiol-17 $\beta$ production in granulosa cells in vitro $[18,19]$ and proliferation of follicular cells $[20,21]$ in vitro. Contradicting, high plasma insulin concentration had negative effects on oocyte maturation in vitro [15] and insulin stimulating diets are possibly beneficial to establish ovarian activity postpartum, but not to establish pregnancy [16]. Therefore, it can be hypothesized that for reproductive performance, with days open being the net result of resumption of ovarian cyclicity and pregnancy rates, an optimal energy balance and metabolic status would be essential rather than a maximal EB or insulin concentration.

Earlier, we reported consequences of reducing postpartum dietary energy level for cows after no DP on energy balance, metabolic status and days open, as compared with cows after $0-\mathrm{d}$ DP or a short DP with standard dietary energy level [9]. The overall aim of the current study was to unravel the effect of reducing postpartum dietary energy level on days open for cows after 0-d DP. The first objective of the current study was to investigate the effects of reducing postpartum dietary energy level 
for cows after 0-d DP on resumption of ovarian cyclicity, and reproductive performance, as compared with cows after $0-\mathrm{dDP}$ or $30-\mathrm{d} \mathrm{DP}$ with standard postpartum dietary energy level. The second objective of this study was to relate days open with other reproductive measures. The third objective of this study was to relate OLA and days open with metabolic status in early lactation.

\section{Materials and Methods}

\subsection{Animals and Housing}

The Institutional Animal Care and Use Committee of Wageningen University \& Research approved the experimental protocol in compliance with the Dutch law on Animal Experimentation as described earlier (protocol number 2014125; Van Hoeij et al., 2017). The experiment was performed from 27 January 2014 until 9 May 2016. Holstein-Friesian dairy cows $(n=128)$ at Dairy Campus research farm (Lelystad, The Netherlands) were selected based on (1) expected calving interval $<490$ days, (2) daily milk yield $>16 \mathrm{~kg}$ at 90 days before the expected calving date and (3) no clinical mastitis and SCC $<250,000$ cells $/ \mathrm{mL}$ at 2 final test days before conventional drying off day. Cows pregnant with twins were excluded from the study. Cows were housed in a free stall barn with a slatted floor and cubicles and were milked twice daily (6:00 and 18:00 h). Cows with a 30-d DP were fed a dry cow ration from 7 days before drying off and milked once daily from 4 days before drying off. 0 -d dry period cow antibiotics were used in any of the cows in this study.

\subsection{Experimental Design}

The experiment was originally designed to study the effects of DP length, dietary energy level, and mid-lactation ration (glucogenic or lipogenic ration) on milk production, milk composition, EB, plasma metabolites, and lactation persistency during a complete lactation [9]. Cows were blocked by expected calving date, milk yield in previous lactation and parity. We aimed for 40 cows per transition treatment, but because of the long-term characteristic of this experiment we included 2 spare blocks and when cows had to be omitted before calving they were replaced. Within each block of 6 cows, 4 cows were assigned randomly to 0 -d dry period (0-d DP) and 2 cows to a short dry period of 30 days (30-d DP). Cows with a 0-d DP were assigned randomly to either a low postpartum dietary energy level (LOW) or a standard postpartum dietary energy level (STD) in early lactation. In the first 3 weeks after calving, dietary energy level was the same for all 3 transition treatments: all cows received $1 \mathrm{~kg}$ of concentrate from 10 days before the expected calving date and from 4 DIM concentrate supply increased stepwise for all transition treatments with $0.3 \mathrm{~kg} / \mathrm{d}$ until $6.7 \mathrm{~kg} / \mathrm{d}$ at 22 DIM [9]. For cows fed the STD diet, concentrate supply was increased further until $8.5 \mathrm{~kg} / \mathrm{d}$ at $28 \mathrm{DIM}$, resulting in a dietary energy level contrast (LOW vs. STD) from 22 DIM onwards (Figure 1). A standard dietary energy level was based on the energy requirement for expected milk yield of 30-d DP cows [21]. All 30-d DP cows were fed an STD. A low dietary energy level was based on the energy requirement for expected milk yield of cows with 0-d DP [21]. Thus, all cows were assigned to one of 3 transition treatments: 0-d DP (LOW) $(n=42), 0-d$ DP (STD) $(n=43), 30-d$ DP (STD) $(n=43)$ (Table 1). From week 8 postpartum onwards, cows received either a glucogenic or lipogenic basal ration. Preliminary analysis showed that mid-lactation ration (glucogenic vs. lipogenic ration) did not affect days open or ovarian cyclicity in the first 100 days in milk (DIM) and was therefore not included in the analysis of this study. 


\begin{tabular}{|c|c|c|c|c|}
\hline \multirow{2}{*}{$\begin{array}{l}\text { 30-d DP } \\
n=43 \text { cows }\end{array}$} & \multirow[t]{2}{*}{ Same diet } & \multirow[t]{2}{*}{ STD } & Lipogenic-STD & \multirow{2}{*}{ 30-d DP(STD) } \\
\hline & & & Glucogenic-STD & \\
\hline \multirow{2}{*}{$\begin{array}{l}0 \text {-d DP } \\
n=43 \text { cows }\end{array}$} & \multirow[t]{2}{*}{ Same diet } & \multirow[t]{2}{*}{ STD } & Lipogenic-STD & \multirow{2}{*}{ - 0-d DP(STD) } \\
\hline & & & Glucogenic-STD & \\
\hline \multirow{2}{*}{$\begin{array}{l}0-\mathrm{d} D P \\
\mathrm{n}=42 \text { cows }\end{array}$} & \multirow[t]{2}{*}{ Same diet } & \multirow[t]{2}{*}{ LOW } & Lipogenic-LOW & \multirow{3}{*}{ - 0-d DP(LOW) } \\
\hline & & & Glucogenic-LOW & \\
\hline & $\begin{array}{l}0 \\
\text { Days }\end{array}$ & & 100 & \\
\hline
\end{tabular}

Progesterone sampling (3x per week)

Figure 1. Overview of experimental design and sampling protocol for cows with different transition treatments. $30-\mathrm{d}$ DP $=30$ days dry period; 0 -d DP $=0$ day dry period; STD = standard energy level; LOW = low energy level.

Table 1. Distribution of cows with 0 (0-d DP) or 30 days (30-d DP) of dry period and fed a low (LOW) or standard (STD) dietary energy level.

\begin{tabular}{ccccc}
\hline Cows, $\mathbf{n}$ & 0-d DP (LOW) & 0-d DP (STD) & 30-d DP (STD) & Total \\
\hline Cows in experiment & 42 & 43 & 43 & 128 \\
Cows with OLA activity within 100 DIM ${ }^{1}$ & 42 & 42 & 43 & 127 \\
Cows with complete 1st ovarian cycle & 41 & 39 & 39 & 119 \\
Cows with complete 2nd ovarian cycle & 32 & 26 & 29 & 87 \\
\hline
\end{tabular}

${ }^{1}$ DIM $=$ Days in milk.

\subsection{Measurements}

\subsubsection{Feed Intake and Energy Balance}

Daily concentrate intake was recorded by a computerized feeder (Manus VC5, DeLaval, Steenwijk, The Netherlands). Daily ration intake was recorded individually using roughage intake control (RIC) troughs and averaged per week (Insentec, Marknesse, The Netherlands).

Energy balance was calculated as net energy (NE) intake minus NE for maintenance, milk yield and pregnancy per week with Dutch NE system for lactation (VEM system; Van Es et al., 1975). According to the Dutch NE system, the daily requirement for maintenance is $42.4 \mathrm{VEM} / \mathrm{kg} 0.75 \mathrm{BW}$ per day, milk yield is $442 \mathrm{VEM} / \mathrm{kg}$ fat- and protein-corrected milk (FPCM). $1000 \mathrm{VEM}$ is equal to 6.9 MJ NE.

\subsubsection{Milk Sampling and Progesterone Assay}

Milk samples were collected three times a week (Monday, Wednesday, and Friday) during morning milking from the day of parturition until 100 DIM. Samples were stored at $-20{ }^{\circ} \mathrm{C}$ until analysis of progesterone (P4) concentration. Milk P4 concentration was measured in whole milk by enzyme immunoassay (Ridgeway Science Ltd., Gloucestershire, UK). The intra-assay and inter-assay coefficients of variation were $4.4 \%$ and $16.7 \%$, respectively.

\subsubsection{Blood Sampling and Analysis}

Blood was collected weekly from calving until 7 weeks postpartum as described earlier [9]. In short, blood samples were collected after the morning milking and between 3 and $1 \mathrm{~h}$ before the morning feeding from the coccygeal vein or artery into evacuated EDTA tubes (Vacuette, Greiner BioOne, Kremsmunster, Austria). Concentrations of NEFA and BHB were measured enzymatically using kit no. 994-75409 from Wako Chemicals (Neuss, Germany) and kit no. RB1007 from Randox Laboratories (Ibach, Switzerland,) respectively [22]. The plasma glucose concentration was measured using kit no. 61,269 from BioMerieux (Marcy l'Etoile, France) [22]. The plasma insulin concentration 
was measured using kit no. PI-12K from EMD Millipore Corporation (Billerica, MA, USA). The plasma IGF-1 concentration was measured using kit no. A15729 from Beckman Coulter (Fullerton, CA, USA).

\subsubsection{Definitions of Ovarian Cyclicity}

First OLA postpartum was defined within 100 DIM as the moment P4 was $4 \mathrm{ng} / \mathrm{mL}$ or higher for 2 or more consecutive milk samples. Ovarian cycle length was defined as the number of days between OLA in one ovarian cycle and the OLA in next ovarian cycle. Regularity of ovarian cyclicity of cows was classified into one of 3 groups according to P4 profile from parturition until 100 DIM [3]:

- Normal ovarian cycle: cycles with 18-24 days in length.

- $\quad$ Prolonged ovarian cycle: cycles with more than 24 days in length.

- Short ovarian cycle: cycles with less than 18 days in length.

The percentages of the different type of cycles per cow were calculated within 100 DIM.

\subsection{Reproduction Protocol}

Cows were inseminated after a voluntary waiting period (VWP) of 50 days until at least 170 DIM. Artificial insemination was performed $12 \mathrm{~h}$ after oestrous detection by Lely Qwes-HR Activity Tags (Lely, Maassluis, The Netherlands). Every 4 weeks, pregnancy of cows that were inseminated more than 30 days ago was checked by ultrasound.

\subsection{Statistical Analysis}

Data of 128 cows until 100 DIM were collected, among which 6 cows were entered twice. The numbers of cows per treatment, cows with OLA, cows with complete 1st ovarian cycle and complete 2nd ovarian cycle within 100 DIM are presented in Table 1.

First, regularity of ovarian cyclicity (percentages of normal, prolonged and short cycles per cow within 100 DIM) was analysed with the GLIMMIX procedure of SAS (Version 9.2; SAS institute, Inc., Cary, NC, USA). Fixed effects in the model were transition treatments (0-d DP (LOW), 0-d DP (STD), 30-d DP (STD)) and parity class (2 or $\geq 3$ ).

Second, days open, days to first OLA, length of first luteal phase, length of first follicular phase and length of the first complete postpartum ovarian cycle, were analysed with MIXED procedure of SAS (Version 9.4; SAS Institute, Inc., Cary, NC, USA). Fixed effects in the model were transition treatments (0-d DP (LOW), 0-d DP (STD), 30-d DP (STD)) and parity class (2 or $\geq 3$ ).

Third, MIXED procedure of SAS was used to analyse differences in plasma metabolites, hormones and EB among classes for days open or days to OLA. Cows were classified into one of three days open classes with similar animal numbers (short $<80 \mathrm{~d}$, medium 80 to $130 \mathrm{~d}$, long $>130 \mathrm{~d}$ ). Cows that did not conceive were included as a fourth days open category (not pregnant) in order to include the full database. Cows were also classified based on days to OLA $(<21, \geq 21$ DIM; Chen J., 2015a). Weekly plasma concentrations of glucose, NEFA, BHB, IGF-1, insulin, and EB in week 1 till 7 postpartum. The natural logarithm of the plasma NEFA and BHB concentration were calculated to approximate normal distribution of these variables and were used in all statistical analyses. Subsequently, fixed effects in the model were either days open class or OLA class, and always transition treatment (0-d DP (LOW), 0-d DP (STD), 30-d DP (STD)) and parity class (2 or $\geq 3$ ) and time (week relative to calving). Cow was considered as the repeated subject. Model assumptions were evaluated by examining the distribution of residuals. Values are presented as the least square mean with their standard errors of the mean. Differences were regarded as significant if $p<0.05$, and trends were discussed if $p<0.10$. When present $(p<0.05)$, interactions were clarified in a figure.

\section{Results}

The actual dry period length (DP) of cows with 30-d DP (STD) was $30 \pm 6 \mathrm{~d}$, the DP of cows with 0-d DP (LOW) or 0-d DP (STD) was $0 \mathrm{~d}$. Results on EB and metabolic status after different transition 
treatments in the current experiment were reported earlier [9]. In short, reducing the level of energy in early lactation for cows after 0-d DP reduced EB both from week 4 till 7 [9] and from week 8 till 44 [23] postpartum, compared with a standard energy level after 0-DP. Postpartum, EB of cows with a 30-DP was more negative than of cow with a $0-\mathrm{d} D P$, the more negative EB was reflected in a greater plasma NEFA and BHB concentration, and a lower plasma glucose, insulin and IGF-1 concentration during weeks 4 and 7, compared with cows with a 0 -d DP.

\subsection{Effect of Transition Treatments on Days Open and Ovarian Activity}

The effect of transition treatments on days open was dependent on parity (Table 2; Figure 2a). For young cows (parity 2), there was no effect of different transition treatments on days open $(99.9,96.6$ vs. $119.9 \mathrm{~d}$ for 0-d DP (LOW), 0-d DP (STD) vs. 30-d DP (STD); $p=0.13$ ). Older cows (parity $\geq 3$ ), however, had less days open with 0-d DP (LOW), compared with older cows with 0-d DP (STD) (105.2 vs. 182.3, $137.8 \mathrm{~d}$ for 0-d DP (LOW) vs. 0-d DP (STD), 30-d DP (STD); $p<0.01$ ).

Table 2. Reproduction measures and incidence of normal and abnormal ovarian cyclicity within 100 days in milk (DIM) of cows with different transitiontreatments 1 .

\begin{tabular}{|c|c|c|c|c|c|c|c|c|c|c|}
\hline \multirow[b]{3}{*}{ Parity } & \multicolumn{6}{|c|}{ Transition Treatments } & \multirow{3}{*}{ SEM } & \multicolumn{3}{|c|}{$p$-Value ${ }^{2}$} \\
\hline & \multicolumn{2}{|c|}{ 0-d DP (LOW) } & \multicolumn{2}{|c|}{ 0-d DP (STD) } & \multicolumn{2}{|c|}{ 30-d DP (STD) } & & \multirow[t]{2}{*}{ TT } & \multirow[t]{2}{*}{$\mathbf{P}$} & \multirow[t]{2}{*}{$\mathbf{T T} \times \mathbf{P}$} \\
\hline & 2 & $\geq 3$ & 2 & $\geq 3$ & 2 & $\geq 3$ & & & & \\
\hline Cows (n) & 21 & 21 & 22 & 21 & 21 & 22 & & & & \\
\hline Days open (days) & $99.9^{\text {a }}$ & $110.7^{\mathrm{a}}$ & $96.6^{\mathrm{a}}$ & $159.3^{b}$ & $114.9^{\mathrm{a}, \mathrm{b}}$ & $127.5^{\mathrm{a}, \mathrm{b}}$ & 15.0 & $<0.01$ & $<0.01$ & $<0.01$ \\
\hline Calving to first $\mathrm{AI}^{3}$ (days) & 73.5 & 66.9 & 66.1 & 71.9 & 67.7 & 69.0 & 5.0 & 0.97 & 0.48 & 0.50 \\
\hline Services per conception & $2.3^{\mathrm{b}}$ & $2.7^{\mathrm{b}}$ & $2.1^{\mathrm{b}}$ & $4.3^{\mathrm{a}}$ & $2.9^{a, b}$ & $2.7^{\mathrm{b}}$ & 0.4 & 0.27 & 0.02 & $<0.01$ \\
\hline Pregnant within 44 weeks (\%) & 95.2 & 95.2 & 95.4 & 87.1 & 85.2 & 95.5 & 7.1 & 0.96 & 0.90 & 0.99 \\
\hline Pregnant within 100 DIM (\%) & $66.7^{\mathrm{a}}$ & $57.1^{\mathrm{a}, \mathrm{b}}$ & $59.1^{\mathrm{a}, \mathrm{b}}$ & $23.8^{\mathrm{b}}$ & $42.9^{\mathrm{a}, \mathrm{b}}$ & $22.7^{\mathrm{b}}$ & 10.4 & 0.02 & 0.04 & 0.63 \\
\hline Days to 1 st OLA 4 & $17.0^{\mathrm{a}}$ & $21.9^{\mathrm{a}, \mathrm{b}}$ & $20.2^{a, b}$ & $27.6^{\mathrm{b}}$ & $26.3^{a, b}$ & $28.3^{b}$ & 2.6 & $<0.01$ & $<0.01$ & 0.31 \\
\hline Cycle number per cow within 100 DIM & $2.1^{\mathrm{a}, \mathrm{b}}$ & $2.0^{\mathrm{a}, \mathrm{b}}$ & $2.2^{\mathrm{a}}$ & $1.8^{\mathrm{a}, \mathrm{b}}$ & $1.9^{\mathrm{a}, \mathrm{b}}$ & $1.7^{\mathrm{b}}$ & 0.2 & $<0.01$ & $<0.01$ & 0.07 \\
\hline Normal cycles (per cow within 100 DIM) (\%) & 48.6 & 39.6 & 41.7 & 39.7 & 42.0 & 42.1 & 8.4 & 0.48 & 0.44 & 0.29 \\
\hline Short cycles (per cow within 100 DIM) (\%) & $16.5^{\mathrm{a}, \mathrm{b}}$ & $18.1^{\mathrm{a}, \mathrm{b}}$ & $18.5^{\mathrm{a}, \mathrm{b}}$ & $5.9^{\mathrm{a}}$ & $23.2^{b}$ & $7.0^{\mathrm{a}, \mathrm{b}}$ & 5.6 & 0.06 & $<0.01$ & $<0.01$ \\
\hline Prolonged cycles (per cow within 100 DIM) (\%) & $34.9^{\mathrm{a}}$ & $42.40^{\mathrm{a}, \mathrm{b}}$ & $40.9^{\mathrm{a}, \mathrm{b}}$ & $54.4^{\mathrm{b}}$ & $34.8^{\mathrm{a}, \mathrm{b}}$ & $50.9^{\mathrm{a}, \mathrm{b}}$ & 8.6 & 0.02 & 0.09 & 0.45 \\
\hline \multicolumn{11}{|l|}{ 1st ovarian cycle postpartum (days) } \\
\hline Luteal phase length (days) & $18.0^{\mathrm{a}, \mathrm{b}}$ & $18.9^{a, b}$ & $21.0^{\mathrm{a}, \mathrm{b}}$ & $21.8^{\mathrm{a}}$ & $13.9^{b}$ & $17.9^{\mathrm{a}, \mathrm{b}}$ & 2.7 & $<0.01$ & 0.10 & 0.15 \\
\hline Follicular phase length (days) & $6.9^{\mathrm{a}, \mathrm{b}}$ & $10.4^{\mathrm{a}}$ & $7.4^{\mathrm{a}, \mathrm{b}}$ & $6.5^{\mathrm{b}}$ & $8.2^{\mathrm{a}, \mathrm{b}}$ & $9.4^{\mathrm{a}, \mathrm{b}}$ & 1.3 & $<0.01$ & $<0.01$ & $<0.01$ \\
\hline Cycle length (days) & 24.9 & 28.3 & 28.4 & 28.3 & 22.2 & 27.3 & 2.9 & 0.02 & $<0.01$ & 0.09 \\
\hline
\end{tabular}

a,b Values in the same row with different superscripts differ $(p<0.05)^{1}$ Transition treatments were: 0-d dry fed low energy level postpartum (0-d (LOW)); 0-d dry fed a standard energy level postpartum (0-d (STD)); 30-d dry fed a standard energy level postpartum (30-d (STD)); ${ }^{2} \mathrm{TT}=$ Transition treatment; $p=$ Parity. ${ }^{3} \mathrm{AI}=$ Artificial Insemination; ${ }^{4} \mathrm{OLA}=$ Onset of luteal activity.

For young cows, there was no effect of different transition treatments on services per conception. For older cows, cows with 0-d DP (LOW) or 30-d DP (STD) had less services per conception compared with older cows with 0 -d DP (STD) $(2.68,2.71$ vs. 4.31 for 0-d DP (LOW), 30-d DP (STD) vs. 0-d DP (STD); $p<0.01$, respectively) (Figure $2 \mathrm{~b}$ ).

Cows with 0-d DP (LOW) had the greatest percentage of cows pregnant within 100 DIM compared with cows with 0-d DP (STD) or 30-d DP (STD), but there was no effect on the percentage of cows pregnant within 44 weeks. Cows with 0-d DP (LOW) had less days to first OLA compared with cows with 30-d DP (STD) ( $p<0.01)$. Within 100 DIM, cows with a 0-d DP had more ovarian cycles compared with cows with 30-d DP length $(p<0.05)$. Among these cycles, cows with 0 -d DP (LOW) had a lower percentage of prolonged cycles compared with cows with 0-d DP (STD) or 30-d DP (STD). For the first ovarian cycle, cows with 0-d DP (LOW) had shorter luteal phase and longer follicular phase compared with cows in group 0-d DP (STD). 


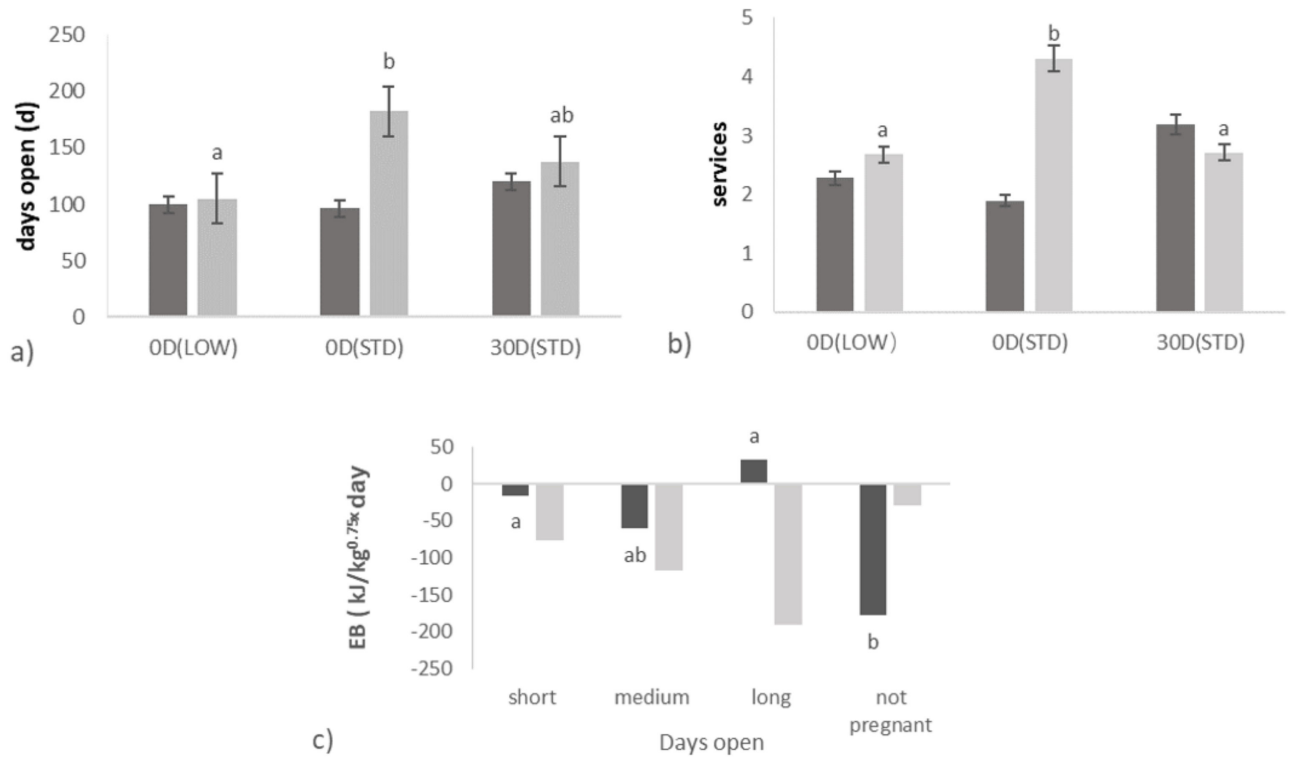

Figure 2. The effect of transition treatments (0-d DP (LOW), 0-d DP (STD), 30-d DP (STD) for cows of different parity classes (parity $=2$ in dark grey or parity $\geq 3$ in light grey) on days open (a), services per pregnancy (b); The relation of days open class (short: $<80 \mathrm{~d}$, medium: $80-130 \mathrm{~d}$, long: $>130 \mathrm{~d}$ and not pregnant) for cows of different parity classes (parity $=2$ in dark grey or parity $\geq 3$ in light grey) with energy balance (EB) in week 1 till 7 of lactation (c); ${ }^{a, b}$ Values within parity class in the same row with different superscripts differ $(p<0.05)$.

\subsection{Relationships between Days Open and Ovarian Activity}

Cows with short $(<80 \mathrm{~d}$ ) and medium (80-130 d) days open had less days from calving till first AI compared with cows with long days open $(>130 \mathrm{~d})(p<0.01)$ (Table 3$)$. Cows with short $(<80 \mathrm{~d})$ and medium (80-130 d) days open had less services per conception compared with cows with long days open $(>130 \mathrm{~d})(p<0.01)$.

Relations between days open and OLA, percentage of normal, short and prolonged cycles and cycle length were depended on transition treatments. Cows with medium days open (80-130 d) with a $0-d$ DP had less days to OLA compared with cows with medium days open with 30-d DP (18.64 d vs. $18.10 \mathrm{~d}, 28.62 \mathrm{~d}$ for 0-d DP (LOW) vs. 0-d DP (STD), 30-d DP (STD) ( $p=0.01)$ ) (Figure A1a). In addition, cows with medium days open (80-130 d) and 0-d DP (LOW) had a greater percentage of normal regular cycles compared with cows with medium days open with 0 -d DP (STD) (48.50 vs. 25.75\%; $p=0.04$ ) (Figure A1b). Cows with days open less than $130 \mathrm{~d}$ (short and medium) had a lower percentage of prolonged ovarian cycles compared with cows with long days open $(>130 \mathrm{~d})$ and cows that did not get pregnant at all $(p<0.01)$. Cows that did not get pregnant had lower percentage of short cycles compared with cows in other groups $(p<0.01)$.

For the first ovarian cycle postpartum, cows with short ( $<80 \mathrm{~d}$ ) and medium (80-130 d) days open had shorter luteal phase and shorter cycle length, compared with cows with long days open $(>130 \mathrm{~d})$ $(p=0.01)$. There was a tendency that cows with short $(<80 \mathrm{~d})$ and medium $(80-130 \mathrm{~d})$ days open had shorter follicular phase compared with cows with long days open $(>130 \mathrm{~d})(p=0.07)$.

\subsection{Relationships between Onset of Luteal Activity and Metabolic Status}

Cows with OLA less than 21 DIM had greater glucose, IGF-1 and insulin concentration, better EB and lower NEFA concentration compared with cows with OLA equal or greater than 21 DIM $(p<0.05)$ (Table 4). For cows with OLA at less than 21 DIM, cows with 0-d DP (LOW) or 0-d DP (STD) had greater insulin concentration than cows with 30-d DP (STD) $(16.69,18.93$ vs. $11.81 \mu \mathrm{IU} / \mathrm{mL}$ for $0-\mathrm{d}$ DP (LOW), 0-d DP (STD) vs. 30-d DP (STD); $p<0.01$ ). 


\subsection{Relationships between Days Open and Metabolic Status}

Relations of days open with plasma concentration of insulin and EB in the first 7 weeks of lactation were dependent on parity (Table 5). Young cows with long $(>130 \mathrm{~d})$ and short $(<80 \mathrm{~d})$ days open had a more positive EB compared with young cows with a medium days open (80-130 d) and cows that did not get pregnant at all ( $p=0.01)\left(32.89,-15.69\right.$ vs. $-60.47,-178.09 \mathrm{~kJ} / \mathrm{kg}^{0.75}$.day for long, short vs. medium days open, not pregnant) (Figure $2 \mathrm{c}$ ). There was a trend that young cows with long days open $(>130 \mathrm{~d})$ had a greater insulin concentration in week 1 till 7 of lactation compared with young cows that did not get pregnant at all (17.47 vs. $10.22 \mu \mathrm{IU} / \mathrm{mL})(p=0.07)$. Cows with short and medium days open $(<130 \mathrm{~d}$ ) had a higher plasma insulin concentration, compared with cows that did not get pregnant at all.

Although EB in the first 7 weeks of lactation was negatively related with days open, this relationship was not so clear when the EB in the first 14 weeks was evaluated in relation with days open class. There was a tendency for the most negative EB in the first 14 weeks for cows with medium days open, compared with cows with short and long days open, which is also illustrated by Figure 3.

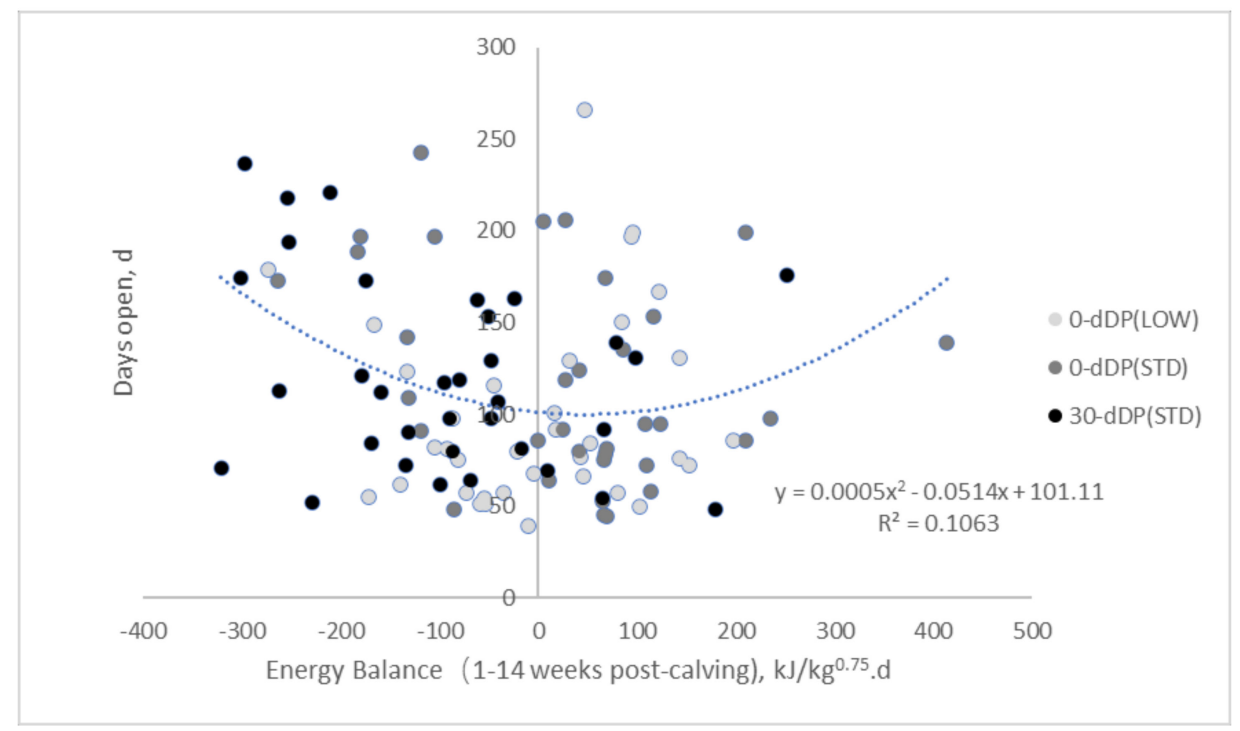

Figure 3. Energy balance for cows with different transition treatments in 1-14 weeks post-calving. Transition treatments were: $0-\mathrm{d}$ dry fed low energy level postpartum (0-d (LOW)); 0-d dry fed a standard energy level postpartum (0-d (STD)); 30-d dry fed a standard energy level postpartum (30-d (STD)). 
Table 3. Relationship between days open and characteristics of ovarian cycles of dairy cows with different transition treatments ${ }^{1}$.

\begin{tabular}{|c|c|c|c|c|c|c|c|c|c|c|c|c|c|}
\hline \multirow[b]{2}{*}{ Variable } & \multicolumn{4}{|c|}{ Days Open } & \multirow[b]{2}{*}{ SEM } & \multicolumn{3}{|c|}{ Transition Treatments } & \multirow[b]{2}{*}{ SEM } & \multicolumn{4}{|c|}{$p$-Value ${ }^{2}$} \\
\hline & Short $(<80 \mathrm{~d})$ & $\begin{array}{c}\text { Mid } \\
(80-130 \mathrm{~d})\end{array}$ & Long (>130 d) & Not Pregnant $^{3}$ & & $\begin{array}{l}\text { 0-d DP } \\
\text { (LOW) }\end{array}$ & $\begin{array}{l}0 \text {-d DP } \\
\text { (STD) }\end{array}$ & $\begin{array}{l}\text { 30-d DP } \\
\text { (STD) }\end{array}$ & & $\begin{array}{l}\text { Days } \\
\text { Open }\end{array}$ & $\mathbf{P}$ & TT & $\begin{array}{c}\text { TT } \times \text { Days } \\
\text { Open }\end{array}$ \\
\hline Cows, $\mathrm{n}$ & 37 & 37 & 37 & 17 & & 42 & 43 & 43 & & & & & \\
\hline Calving to first $\mathrm{AI}^{4}$ (days) & $60.42^{\mathrm{a}}$ & $68.85^{\mathrm{a}}$ & $80.16^{\mathrm{b}}$ & $68.07^{\mathrm{a}}$ & 5.55 & 71.02 & 67.44 & 69.66 & 6.03 & $<0.01$ & 0.48 & 0.97 & 0.83 \\
\hline Services per pregnancy & $1.44^{\mathrm{a}}$ & $2.71^{\mathrm{b}}$ & $4.09^{\mathrm{c}}$ & & 0.36 & 2.36 & 3.31 & 2.57 & 0.16 & $<0.01$ & 0.35 & 0.79 & 0.79 \\
\hline Days to first OLA ${ }^{5}$ & $24.73^{\mathrm{b}}$ & $22.20^{\mathrm{a}}$ & $23.76^{\mathrm{c}}$ & $24.68^{\mathrm{c}}$ & 1.36 & 19.26 & 25.53 & 26.73 & 2.84 & $<0.01$ & $<0.01$ & $<0.01$ & $<0.01$ \\
\hline Cycle number (per cow within 100 DIM) & $1.62^{\mathrm{a}}$ & $2.49^{\mathrm{c}}$ & $2.00^{\mathrm{b}}$ & $1.74^{\mathrm{a}}$ & 0.06 & 2.32 & 1.77 & 1.80 & 0.20 & $<0.01$ & $<0.01$ & $<0.01$ & 0.22 \\
\hline Normal cycles (per cow within 100 DIM) (\%) & $47.96^{\mathrm{a}}$ & $43.98^{\text {a }}$ & $30.47^{\mathrm{b}}$ & $38.83 \mathrm{ab}$ & 4.66 & 42.28 & 40.02 & 38.62 & 6.41 & $<0.01$ & 0.41 & 0.82 & $<0.01$ \\
\hline Short cycles (per cow within 100 DIM) $(\%)$ & $18.01^{\mathrm{a}}$ & $14.93^{\text {a }}$ & $13.74^{\mathrm{a}}$ & $6.76^{\mathrm{b}}$ & 3.06 & 14.40 & 10.65 & 15.04 & 6.45 & $<0.01$ & $<0.01$ & 0.19 & $<0.01$ \\
\hline $\begin{array}{l}\text { Prolonged cycles (per cow within } 100 \text { DIM) }(\%) \\
\text { 1st ovarian cycle postpartum (days) }\end{array}$ & $35.03^{\mathrm{a}}$ & $40.92^{\mathrm{a}}$ & $55.31^{\mathrm{b}}$ & $52.90^{\mathrm{b}}$ & 4.88 & 42.17 & 49.26 & 46.68 & 9.75 & $<0.01$ & 0.10 & 0.66 & $<0.01$ \\
\hline Luteal phase length & $17.94^{\mathrm{a}}$ & $18.22^{\mathrm{a}}$ & $22.03^{\mathrm{b}}$ & $18.29^{\mathrm{b}}$ & 0.74 & 20.18 & 21.01 & 16.16 & 2.92 & $<0.01$ & 0.82 & $<0.01$ & 0.05 \\
\hline Follicular phase length & 7.02 & 7.33 & 9.72 & 7.73 & 0.77 & 8.83 & 6.59 & 8.43 & 1.38 & 0.07 & 0.01 & $<0.01$ & 0.31 \\
\hline Cycle length & $25.00^{\mathrm{a}}$ & $25.28^{\mathrm{a}}$ & $31.89 \mathrm{~b}$ & $25.56^{\mathrm{a}}$ & 1.59 & 28.58 & 27.56 & 24.66 & 3.19 & $<0.01$ & 0.30 & $<0.01$ & $<0.01$ \\
\hline
\end{tabular}

${ }^{a, b}$ Values in the same row with different superscripts differ $(p<0.05) .{ }^{1}$ Transition treatments were: 0 -d dry fed low energy level postpartum $(0-\mathrm{d}(\mathrm{LOW})) ; 0$-d dry fed a standard energy

level postpartum (0-d (STD)); 30-d dry fed a standard energy level postpartum (30-d (STD)); ${ }^{2} \mathrm{TT}=$ Transition treatment; $p=$ Parity. ${ }^{3}$ Cows did not get pregnant through the lactation. ${ }^{4}$ AI

$=$ Artificial Insemination; ${ }^{5}$ OLA $=$ Onset of luteal activity. None of the variables had an interaction between Days open class and parity class, treatments and parity class.

Table 4. Relationship between days to onset of luteal activity (OLA) and postpartum ${ }^{1}$ plasma metabolites and metabolic hormones of cows after different transition treatments ${ }^{2}$

\begin{tabular}{|c|c|c|c|c|c|c|c|c|c|c|c|c|c|c|}
\hline & \multicolumn{2}{|c|}{ Days to OLA } & \multirow[b]{2}{*}{ SEM } & \multicolumn{3}{|c|}{ Transition Treatments } & \multirow[b]{2}{*}{ SEM } & \multicolumn{7}{|c|}{$p$-Value $^{3}$} \\
\hline & $<21 \mathrm{~d}$ & $\geq 21 \mathrm{~d}$ & & $\begin{array}{l}\text { 0-d DP } \\
\text { (LOW) }\end{array}$ & $\begin{array}{l}\text { 0-d DP } \\
\text { (STD) }\end{array}$ & $\begin{array}{l}\text { 30-d DP } \\
\text { (STD) }\end{array}$ & & OLA & TT & $\mathbf{P}$ & $\mathbf{W}$ & OLA $\times$ TT & OLA $\times \mathbf{P}$ & $\mathrm{OLA} \times \mathbf{W}$ \\
\hline Cows, $n$ & 66 & 53 & & & & & & & & & & & & \\
\hline Glucose $(\mathrm{mmol} / \mathrm{L})^{4}$ & $3.92^{\mathrm{a}}$ & $3.71^{\mathrm{b}}$ & 0.05 & 3.89 & 3.90 & 3.66 & 0.04 & $<0.01$ & $<0.01$ & $<0.01$ & $<0.01$ & 0.21 & 0.15 & 0.65 \\
\hline $\mathrm{NEFA}(\mathrm{mmol} / \mathrm{L})^{4}$ & $\begin{array}{c}0.11^{\mathrm{a}} \\
(0.10-0.13)\end{array}$ & $\begin{array}{c}0.20^{\mathrm{b}} \\
(0.17-0.22)\end{array}$ & & $\begin{array}{c}0.12 \\
(0.11-0.14)\end{array}$ & $\begin{array}{c}0.12 \\
(0.10-0.14)\end{array}$ & $\begin{array}{c}0.23 \\
(0.20-0.26)\end{array}$ & & $<0.01$ & $<0.01$ & $<0.01$ & $<0.01$ & 0.47 & 0.01 & 0.24 \\
\hline BHB $(\mathrm{mmol} / \mathrm{L})^{4}$ & $\begin{array}{c}0.63^{\mathrm{a}} \\
(0.59-0.67)\end{array}$ & $\begin{array}{c}0.73^{\mathrm{b}} \\
(0.68-0.79)\end{array}$ & & $\begin{array}{c}0.66 \\
(0.60-0.72)\end{array}$ & $\begin{array}{c}0.64 \\
(0.59-0.69)\end{array}$ & $\begin{array}{c}0.74 \\
(0.69-0.80)\end{array}$ & & $<0.01$ & 0.02 & $<0.01$ & 0.01 & 0.01 & 0.07 & 0.36 \\
\hline IGF-1 (ng/mL) ${ }^{4}$ & $129.11^{\mathrm{a}}$ & $95.31^{\mathrm{b}}$ & 6.48 & 122.63 & 121.82 & 92.17 & 5.39 & $<0.01$ & $<0.01$ & $<0.01$ & $<0.01$ & 0.29 & 0.43 & 0.01 \\
\hline Insulin $(\mu \mathrm{IU} / \mathrm{mL})^{4}$ & $15.86^{\mathrm{a}}$ & $11.41^{\mathrm{b}}$ & 0.82 & 14.58 & 15.51 & 10.81 & 0.68 & $<0.01$ & $<0.01$ & 0.86 & $<0.01$ & 0.10 & 0.71 & 0.08 \\
\hline $\mathrm{EB}\left(\mathrm{kJ} / \mathrm{kg}^{0.75}\right.$.day $)(\text { week } 1 \text { till } 7)^{5}$ & $-15.52^{\text {a }}$ & $-153.05^{b}$ & 26.61 & -55.59 & -18.33 & -178.94 & 22.11 & $<0.01$ & $<0.01$ & 0.06 & $<0.01$ & 0.22 & $<0.01$ & 0.19 \\
\hline
\end{tabular}

a,b Values with different superscripts differ $(p<0.05) .{ }^{1}$ Postpartum = weeks 1 to 7 after calving. ${ }^{2}$ Transition treatments were: 0-d dry fed low energy level postpartum $(0-\mathrm{d}(\mathrm{LOW})) ; 0$-d dry

fed a standard energy level postpartum (0-d (STD)); 30-d dry fed a standard energy level postpartum (30-d (STD)). ${ }^{3} \mathrm{TT}=$ Transition treatment; $p=$ Parity; $\mathrm{W}=\mathrm{Week}$ relative to calving.

${ }^{4}$ Concentration in plasma was measured weekly between weeks 1-7 post-calving. Non-esterified fatty acids (NEFA) and $\beta$-hydroxybutyrate (BHB) were log transformed for analysis,

but are shown as actual values with confidence interval. ${ }^{5} \mathrm{~EB}=$ Energy balance. None of the variables had an interaction between treatments and parity class 
Table 5. Relationship between days open classes and postpartum ${ }^{1}$ plasma metabolites and metabolic hormones of cows after different transition treatments ${ }^{2}$

\begin{tabular}{|c|c|c|c|c|c|c|c|c|c|c|c|c|c|c|c|c|}
\hline & \multicolumn{4}{|c|}{ Days Open } & \multirow[b]{2}{*}{ SEM } & \multicolumn{3}{|c|}{ Transition Treatments } & \multirow[b]{2}{*}{ SEM } & \multicolumn{7}{|c|}{$p$-Value ${ }^{3}$} \\
\hline & $<80 \mathrm{~d}$ & $80-130 \mathrm{~d}$ & $>130 \mathrm{~d}$ & $\begin{array}{c}\text { Not } \\
\text { Pregnant }\end{array}$ & & $\begin{array}{l}\text { 0-d DP } \\
\text { (LOW) }\end{array}$ & $\begin{array}{l}\text { 0-d DP } \\
\text { (STD) }\end{array}$ & $\begin{array}{c}\text { 30-d DP } \\
\text { (STD) }\end{array}$ & & $\begin{array}{l}\text { Days } \\
\text { Open }\end{array}$ & TT & $\mathbf{P}$ & $\mathrm{w}$ & $\begin{array}{c}\text { Days } \\
\text { Open } \times \mathbf{P}\end{array}$ & $\begin{array}{c}\text { Days } \\
\text { Open } \times \text { TT }\end{array}$ & $\begin{array}{c}\text { Days } \\
\text { Open } \times W\end{array}$ \\
\hline & 34 & 34 & 37 & 13 & & & & & & & & & & & & \\
\hline Glucose $(\mathrm{mmol} / \mathrm{L})^{4}$ & 3.86 & 3.81 & 3.81 & 3.71 & 0.62 & 3.87 & 3.91 & 3.64 & 0.05 & 0.89 & $<0.01$ & 0.04 & $<0.01$ & 0.73 & 0.88 & 0.28 \\
\hline NEFA $(\mathrm{mmol} / \mathrm{L})^{4}$ & 0.12 & 0.15 & 0.15 & 0.16 & & 0.13 & 0.10 & 0.22 & & 0.12 & $<0.01$ & $<0.01$ & $<0.01$ & $<0.01$ & 0.44 & 0.53 \\
\hline & $(0.09-0.14)$ & $(0.13-0.18)$ & $(0.12-0.18)$ & $(0.12-0.20)$ & & $(0.11-0.16)$ & $(0.08-0.12)$ & $(0.19-0.26)$ & & & & & & & & \\
\hline BHB $(\mathrm{mmol} / \mathrm{L})^{4}$ & $\begin{array}{c}0.66 \\
(0.59-0.73)\end{array}$ & $\begin{array}{c}0.67 \\
(0.61-0.74)\end{array}$ & $\begin{array}{c}0.73 \\
(0.66-0.80)\end{array}$ & $\begin{array}{c}0.66 \\
(0.58-0.76)\end{array}$ & & $\begin{array}{c}0.69 \\
(0.62-0.76)\end{array}$ & $\begin{array}{c}0.62 \\
(0.56-0.68)\end{array}$ & $\begin{array}{c}0.73 \\
(0.67-0.80)\end{array}$ & & 0.53 & 0.03 & 0.12 & $<0.01$ & 0.43 & 0.85 & 0.53 \\
\hline IGF-1 $(\mathrm{ng} / \mathrm{mL})^{4}$ & $\begin{array}{c}(0.59-0.73) \\
122.26\end{array}$ & $\begin{array}{c}(0.61-0.74) \\
116.49\end{array}$ & $\begin{array}{c}(0.66-0.80) \\
111.48\end{array}$ & $\begin{array}{c}(0.58-0.76) \\
105.99\end{array}$ & 7.24 & $\begin{array}{c}(0.62-0.76) \\
122.04\end{array}$ & $\begin{array}{c}(0.56-0.68) \\
128.34\end{array}$ & $\begin{array}{c}(0.67-0.80) \\
91.79\end{array}$ & 6.61 & 0.72 & 0.73 & 0.37 & $<0.01$ & 0.42 & 0.87 & 0.10 \\
\hline Insulin $(\mu \mathrm{IU} / \mathrm{mL})^{4}$ & $14.88^{\mathrm{a}}$ & $14.07^{\mathrm{a}}$ & $13.75^{\mathrm{ab}}$ & $12.12^{\mathrm{b}}$ & 0.98 & 14.04 & 16.42 & 10.65 & 0.78 & $<0.01$ & $<0.01$ & 0.42 & $<0.01$ & $<0.01$ & 0.92 & 0.57 \\
\hline $\mathrm{EB}\left(\mathrm{kJ} / \mathrm{kg}^{0.75} \cdot\right.$ day $)(\text { week } 1 \text { till } 7)^{5}$ & $-48.34^{a}$ & $93.09^{\mathrm{b}}$ & $92.98^{\mathrm{b}}$ & $-118.71^{b}$ & 31.64 & -87.88 & 2.54 & -179.51 & 38.84 & $<0.01$ & 0.09 & 0.90 & $<0.01$ & $<0.01$ & 0.58 & 0.21 \\
\hline $\mathrm{EB}\left(\mathrm{kJ} / \mathrm{kg}^{0.75} \text {.day) (week } 1 \text { till } 14\right)^{5}$ & -15.86 & -26.47 & -10.98 & -33.50 & 21.53 & -23.32 & 49.36 & -91.15 & 20.60 & 0.05 & 0.02 & 0.02 & 0.36 & 0.05 & 0.72 & 0.37 \\
\hline
\end{tabular}

a,b Values with different superscripts differ $(p<0.05) .{ }^{1}$ Postpartum = weeks 1 to 7 after calving, unless otherwise stated; ${ }^{2}$ Transition treatments were: 0 -d dry fed low energy level postpartum (0-d(LOW)); 0-d dry fed a standard energy level postpartum (0-d (STD)); 30-d dry fed a standard energy level postpartum (30-d (STD)); ${ }^{3}$ TT = Transition treatments; $\mathrm{P}=$ Parity; $\mathrm{W}=$ Week relative to calving. ${ }^{4}$ Concentration in plasma was measured weekly between weeks $1-7$ post-calving. NEFA and BHB were log transformed for analysis, but are shown as actual values with confidence interval. ${ }^{5} \mathrm{~EB}=$ Energy balance. ${ }^{6}$ Cows did not get pregnant through the lactation. None of the variables had an interaction between treatments and parity class. 


\section{Discussion}

Reducing postpartum dietary energy level for older cows (parity $\geq 3$ ) after no DP (0-d DP (LOW)) reduced days open with 77.1 and 32.5 days compared with older cows fed postpartum a standard dietary energy level after no DP (0-d DP (STD)) or after a short DP of $30 \mathrm{~d}(30-\mathrm{d}$ DP (STD)). This reduction in days open was partly related with less days postpartum to OLA, partly to less services per conception, and possibly to less prolonged cycles for cows with 0-d DP (LOW), compared with cows with 0-d DP (STD) or cows with 30-d DP (STD). In addition, in earlier studies, omitting of the DP resulted in a reduced interval from calving to first ovulation and less days open compared with 28 or $56 \mathrm{~d}$ dry period [4,24]. Our results also show that cows with 0 -d DP had less days to OLA and more cycle numbers within 100 DIM compared with cows with 30-d DP. Several studies have observed positive effects of an earlier first ovulation after calving on fertility in dairy cows [25-27]. Cows with early first ovulation had more ovulatory cycles before first service compared with cows with late ovulation [27]. Minimizing the interval to first ovulation provides ample time for multiple ovarian cycles prior to insemination, which in turn improves conception rate and reduces inseminations per pregnancy [28]. In our study, a dietary energy level was similar among transition treatments till 21 DIM. Part of the cows ovulated before the dietary energy level contrast was present (32/42, 28/43 and 19/43 for 0-d DP (LOW), 0-d (STD) and 30-d (STD). This implies that only for cows with a delayed first ovulation ( $>21$ DIM) could the dietary energy level contrast have an effect. This resulted in the fact that, on average, cows with 0 -d DP (LOW) had a 4.4 days earlier OLA than cows with $0-d$ DP (STD). Moreover, the older cows (parity $\geq 3$ ) with 0 -d DP (LOW) also had 1.6 fewer services per conception than cows with a $0-d$ DP (STD), which contributed more to a reduction in days open of older cows with 0-d DP (LOW). Gumen et al. [4] also found that the number of services per conception was lower for cows with no DP (1.75) than for cows with a standard DP (3.00), with cows with a short DP being intermediate (2.44).

No improvement in days open was found in young cows with different transition treatments in our study. Watters et al. [1] also reported that reduction in days open $(20 \mathrm{~d})$ and an increase in pregnancy rate per insemination after 34-d DP were only observed in older cows (parity $\geq 3$ ) and not in young cows (cows going from first to second lactation) when compared with cows with 55-d DP. Smith and Wallace [29] reported that ovulation before 21 DIM was associated with reduced pregnancy rates, increased services per pregnancy, and a prolonged calving to pregnancy interval for multiparous, but not primiparous dairy cows. In our results, both younger and older cows had fewer days to OLA after no DP, compared with cows with a short DP, but only older cows had shorter days open. Differences in response of older vs. younger cows to shortening or omitting the DP to fertility measures could be due to the relative priority of young cows for growth, as observed in another study on shortening of the DP [1] and a study on improving metabolic status by a more glucogenic diet [23].

In the current study, cows with 0-d DP had more ovarian cycles within 100 DIM compared with cows with 30-d DP. In addition, cows with 0-d DP (LOW) had a lower incidence of prolonged cycles compared with cows with 0-d DP (STD) or cows with 30-d DP (STD), which can be related to shorter luteal phase length and follicular phase length. The prolonged luteal phase is one of the most common ovarian disturbances in dairy cows [30]. Studies reported that cows with prolonged luteal phase had a lower first AI conception rate, more services per conception, and more days open compared with cows with normal ovarian cycles [30-32]. The most important risk factors for developing prolonged luteal phases are puerperal problems, such as metritis and mastitis. The ratio of prostaglandin E2 (PGE2) to prostaglandin F2 $\alpha$ (PGF2 $\alpha$ ) decides the fate of the corpus luteum, with persistence if PGE2 dominates or luteolysis if PGF2 $\alpha$ dominates [33]. Lipopolysaccharide stimulates the secretion of prostaglandins and particularly PGE2 [34]. Metritis and mastitis could compromise release of prostaglandin F2 $\alpha$ (PGF2 $\alpha$ ) $[30,35,36]$ by increasing lipopolysaccharide in postpartum cows [37], thereby delaying luteolysis, which results in a prolonged luteal phase [38]. In our study, however, no significant differences were found in the incidence of metritis and mastitis between the different transition treatments, the incidence of metritis in two groups were $7.1 \%$ and $4.7 \%$, though the incidence 
of mastitis in transition treatment 0-d DP (LOW) was 31\%, which was numerically lower than $40 \%$ in transition treatment 0-d DP (STD). A high milk yield is also one of the major risk factors for a prolonged luteal phase in high-producing dairy cows [39]. In addition, in the current study, the milk yield of cows with 30-d DP (STD) was greater than that of cows with 0-d DP (LOW) or 0-d DP (STD) (30.3 vs. $24.2,24.7 \mathrm{~kg} / \mathrm{d})(p<0.01)$.

The second objective of the current study was to relate days open of dairy cows after different transition treatments to underlying reproductive measures. Short ( $<80 \mathrm{~d}$ ) and medium (80-130 d) days open was related to a short interval form calving to first AI, compared with long days open. This is in accordance with Harrison [40], who observed that average days open was positively related $\left(\mathrm{r}^{2}=0.99\right)$ to the interval to first $\mathrm{AI}$ in a field study in 12 commercial dairy herds in Michigan. In that study, the first insemination was directly decided by the time of the first ovulation after calving. Additionally, prolonged days open was related with a high number of services per conception [41]. In our study, short ( $<80 \mathrm{~d}$ ) days open was related to less days to OLA, which can also partly reveal the occurrence of delayed resumption of ovarian cyclicity [30,35]. Gautam et al. [42] reported that delayed resumption of ovarian activity adversely influenced the hazard of pregnancy, which was partly driven by a delay in first AI as well as by a substantial reduction in the first AI conception rate. In our study, more days open was not only related to delayed OLA, but also to an increased number of services per pregnancy.

The third objective of the current study was to relate days open and OLA of cows after different transition treatments to their metabolic status in early lactation. Independent of transition treatment with OLA at less than 21 DIM had a better EB during weeks 1 to 7 and the concentration of IGF-1 and insulin were greater compared with cows with OLA equal or greater than 21 DIM. The more negative EB in cows with OLA equal or greater than 21 DIM is possibly related with a compromised ovarian follicular development by suppressed plasma IGF-1 concentration and pituitary luteinizing hormone (LH) pulsatility [43]. This negatively impacts reproduction as IGF-1 is unable to synergise with the gonadotrophins on ovarian cells preventing the dominant follicle from ovulating [44] and delaying the resumption of cyclicity [45], at last leading to a prolonged interval from calving to first ovulation [30]. We also noticed that cows with OLA equal or greater than 21 DIM had a lower concentration of glucose and tended to have a greater NEFA concentration compared with cows with OLA at less than 21 DIM. Greater concentrations of circulating NEFAs were associated with lower follicular estradiol concentrations, impairing ovulation of the dominant follicle [46]. Prolonged intervals from calving to first ovulation have been related to uterine infection [35], mastitis [47,48], and lameness [48]. Like discussed above, also, in the current study, cows with more prolonged cycles (0-d DP (STD) had the numerically greatest incidence of mastitis in early lactation.

In the current study, cows with long days open $(>130 \mathrm{~d})$ or cows that did not get pregnant at all had greater plasma concentration of NEFA as well as a more severe negative EB than cows with short $(<80 \mathrm{~d})$ days open. Multiple studies have reported a negative relationship of NEFA with reproduction $[49,50]$. Increased NEFA concentrations during the transition period were associated with decreased pregnancy rate at first $\mathrm{AI}$ [46] or at $70 \mathrm{~d}$ after the voluntary waiting period [51], whereas another study in 60 free stall herds found that high circulating NEFA was associated with a reduced 21-d pregnancy rate after a voluntary waiting period [52]. All of these studies found positive relations between plasma NEFA and days to OLA and days open, as reported in the current study. Greater concentration of NEFA during a period of negative EB may prevent follicle development, interrupt the complicated endocrine system, and advance the formation of ovarian cysts [53]. In contrast, a low plasma NEFA concentration, combined with a positive EB, was maybe related to an earlier postovulatory increase of progesterone, a greater follicle development, and a better resumption of ovarian activity, resulting in fewer days open. In addition, long days open in young cows could be related with a too positive EB and high insulin concentration, while the cows with short days open had the medium insulin concentration and EB. As shown by Armstrong [13], high energy intake leading to higher insulin concentrations increased the growth rate of the dominant follicle but impaired oocyte quality. Energy balance was positively correlated with the number of large follicles in ovary, and negatively correlated with the 
numbers of small and medium follicles [54]. However, cows with medium-sized follicles (between 14.5 and $17.5 \mathrm{~mm}$ ) had a greater pregnancy rate than cows with follicles of other sizes [55].

Remarkably, multiparous cows after 0-d DP and fed postpartum a standard energy level did not have a reduction in days open, as we saw for cows after 0-d DP and fed postpartum a low energy level, compared with cows which were practically overfed like cows on 0-d (STD). Uterine recovery after parturition and at the same time producing milk to feed the new-born, and remain a healthy and functional dairy cow, can be considered highly energy-demanding processes. Cows fed postpartum a standard energy level after 0-d DP, however, were characterized by more days open, lower pregnancy rates within 100 DIM, more services per conception and more prolonged cycles, compared with cows fed postpartum a low energy level after 0-d DP. This is in line with Watters et al. [1], that both young and old cows with a short DP (34 d) and fed a low postpartum energy level had fewer days to first ovulation, compared with cows with a traditional DP ( $55 \mathrm{~d})$. Still, in our study, only the older cows had earlier time to pregnancy when postpartum dietary energy level was reduced after 0-d DP. It is unknown why cows with 0-d DP (STD) treatment had a lower fertility (more days open, lower pregnancy rates within 100 DIM) compared with cows with 0-d DP (LOW) treatment. It can be speculated, however, that the EB is possibly too positive in early lactation in this group (-2 vs. $55 \mathrm{~kJ} / \mathrm{kg}^{0.75}$ day for 0-d DP (LOW) vs. 0-d DP (STD), respectively) [9]. As discussed above, too high plasma insulin concentration had negative effects on oocyte maturation in vitro [19] and insulin stimulating diets are possibly beneficial to establish ovarian activity postpartum, but not to establish pregnancy [20]. Diets designed to increase plasma insulin concentration had negative effects on blastocyst rate in heifers $[56,57]$ and in lactating dairy cows [58]. Moreover, this implies that not only a severe NEB is detrimental for reproductive performance, but also a positive EB with elevated insulin levels in plasma can have negative consequences for reproduction in dairy cows. This is in line with our findings, where, on the one hand, early OLA was related to a greater plasma insulin concentration, while, on the other hand, days open was not related to plasma insulin concentration in early lactation. Moreover, a nonlinear relationship between EB and days open would clarify why both the treatment group with the best EB in early lactation (0-d DP (STD)) and the treatment group with the most negative EB (30-d DP (STD)) have similar days open which was longer that the treatment group with an intermediate EB (0-d DP (LOW)). It can be speculated that cows with 0-d DP (LOW) had a more optimal EB than cows with a 0-d DP (STD) or 30-d DP (STD) to support fertility.

\section{Conclusions}

Reducing postpartum dietary energy level for older cows (parity $\geq 3$ ) after no DP (0-d DP (LOW)) improved fertility by reducing the interval from calving to OLA, reducing services per conception and consequently reducing days open compared with a standard dietary energy level after no DP (0-d DP (STD)) or after $30 \mathrm{~d}(30-\mathrm{d}$ DP (STD)). Less days to OLA ( $<21 \mathrm{~d})$ was associated with a better metabolic status, indicated by a greater concentration of glucose, IGF-1, and insulin and a lower concentration of NEFA and BHBA during weeks 1 through 7 postpartum. A low number of days open $(<80-\mathrm{d})$ was associated with less days to OLA, less services per conception, better EB in week 1 till 7 of lactation and better metabolic status. Energy balance in week 1 till 14 of lactation, however, was not linearly related with days open. This might indicate that cows with an intermediate EB in week 1 till 14 of lactation (0-d DP (LOW)) had a more optimal EB to support fertility than cows with a positive EB (0-d DP (STD)) or cows with most negative EB (30-d DP (STD)) in week 1 till 14 of lactation.

Author Contributions: Conceptualization, A.T.M.v.K. and B.K.; methodology and investigation, A.T.M.v.K., R.J.v.H., and R.M.B.; writing—original draft preparation, J.M. and A.T.M.v.K.; writing—review and editing, J.M., A.T.M.v.K., R.J.v.H., A.K., R.M.B., T.J.G.M.L., and B.K.; supervision, A.T.M.v.K., T.J.G.M.L., and B.K.; project administration, A.T.M.v.K. and B.K.; funding acquisition, A.T.M.v.K. and B.K. All authors have read and agreed to the published version of the manuscript.

Funding: This experiment was funded by DairyNL (Zuivel NL; organization of the Dutch dairy supply chain, The Netherlands) and the Dutch Ministry of Economic Affairs (EZ, The Netherlands). This study is part of the PhD study of Junnan Ma for which she received a scholarship from China Scholarship Council. 
Acknowledgments: We thank Ger de Vries Reilingh and Rudi Koopmanschap for their technical support and laboratory analyses during the experiment.

Conflicts of Interest: The authors declare no conflict of interest.

\section{Appendix A}

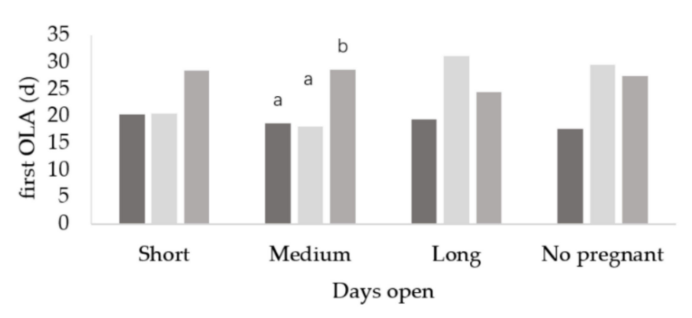

(a)

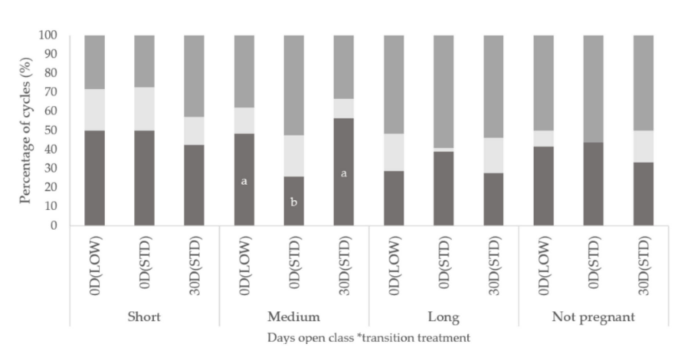

(b)

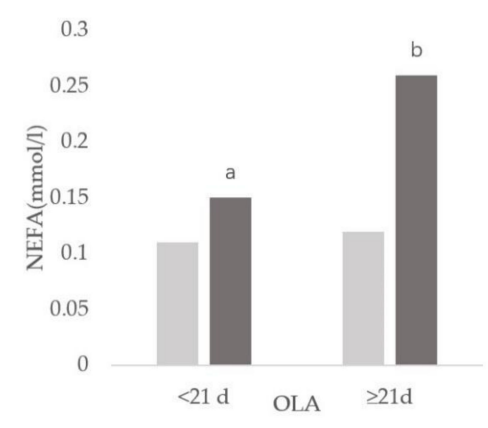

(c)

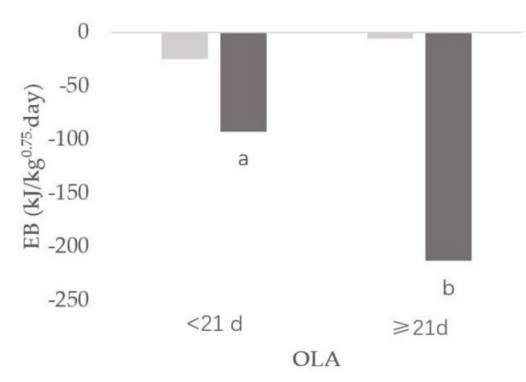

(d)

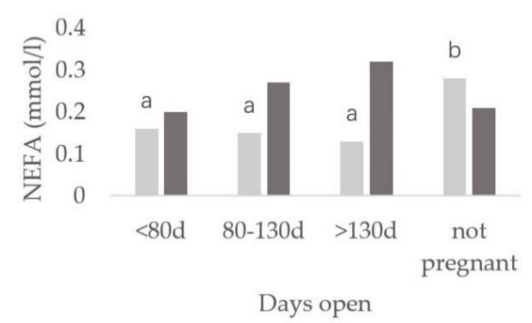

(e)

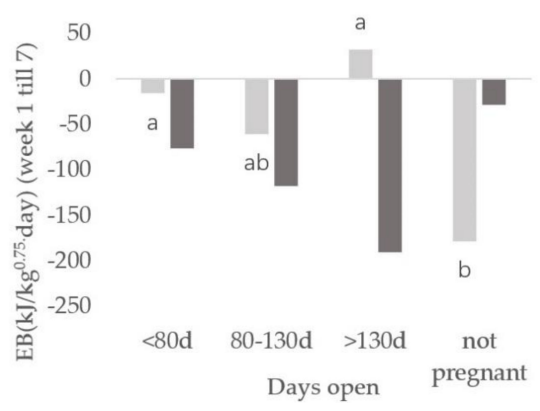

(f)

Figure A1. (a) interactions of different days open (short: $<80 \mathrm{~d}$, medium:80-130 d, long: $>130 \mathrm{~d}$ and not pregnant) with different transition treatment (0-d DP (LOW) in dark grey, 0-d (STD) in light grey, 30-d DP (STD) in grey) for days to first OLA; (b) interactions of different days open (short: $<80 \mathrm{~d}$, medium:80-130 d, long:>130 d and not pregnant) with different transition treatment (0-d DP (LOW), 0-d (STD), 30-d DP (STD)) for different ovarian cycles (normal cycles (in dark grey), short cycles (in light grey) and prolonged cycles (in grey)); (c) interactions of different OLA ( $<21 \mathrm{~d}, \geq 21 \mathrm{~d}$ ) with different parity class (parity $=2$ in light grey, parity $\geq 3$ in dark grey) for plasma non-esterified fatty acid (NEFA) concentration; (d) interactions of different OLA ( $<21 \mathrm{~d}, \geq 21 \mathrm{~d}$ ) with different parity class (parity $=2$ in light grey, parity $\geq 3$ in dark grey) for energy balance (EB); (e) interactions of different days open (short: $<80 \mathrm{~d}$, medium:80-130 d, long: $>130 \mathrm{~d}$ and not pregnant) with different parity class (parity $=2$ in light grey, parity $\geq 3$ in dark grey) for plasma non-esterified fatty acid (NEFA) concentration; (f) interactions of different days open (short: $<80 \mathrm{~d}$, medium:80-130 d, long: $>130 \mathrm{~d}$ and not pregnant) with different parity class (parity $=2$ in light grey, parity $\geq 3$ in dark grey) for energy balance (EB). 


\section{References}

1. Watters, R.; Wiltbank, M.C.; Guenther, J.; Brickner, A.; Rastani, R.; Fricke, P.; Grummer, R. Effect of dry period length on reproduction during the subsequent lactation. J. Dairy Sci. 2009, 92, 3081-3090. [CrossRef] [PubMed]

2. Santschi, D.E.; Lefebvre, D.; Cue, R.; Girard, C.; Pellerin, D. Incidence of metabolic disorders and reproductive performance following a short (35-d) or conventional (60-d) dry period management in commercial Holstein herds. J. Dairy Sci. 2011, 94, 3322-3330. [CrossRef] [PubMed]

3. Chen, J.; Soede, N.; Van Dorland, H.; Remmelink, G.; Bruckmaier, R.; Kemp, B.; Van Knegsel, A.T. Relationship between metabolism and ovarian activity in dairy cows with different dry period lengths. Theriogenology 2015, 84, 1387-1396. [CrossRef] [PubMed]

4. Gümen, A.; Rastani, R.; Grummer, R.; Wiltbank, M.C. Reduced Dry Periods and Varying Prepartum Diets Alter Postpartum Ovulation and Reproductive Measures. J. Dairy Sci. 2005, 88, 2401-2411. [CrossRef]

5. Pezeshki, A.; Mehrzad, J.; Ghorbani, G.; Rahmani, H.; Collier, R.; Burvenich, C. Effects of Short Dry Periods on Performance and Metabolic Status in Holstein Dairy Cows. J. Dairy Sci. 2007, 90, 5531-5541. [CrossRef]

6. Pezeshki, A.; Mehrzad, J.; Ghorbani, G.R.; De Spiegeleer, B.; Collier, R.; Burvenich, C. The effect of dry period length reduction to 28 days on the performance of multiparous dairy cows in the subsequent lactation. Can. J. Anim. Sci. 2008, 88, 449-456. [CrossRef]

7. Chen, J.; Gross, J.J.; Van Dorland, H.; Remmelink, G.; Bruckmaier, R.; Kemp, B.; Van Knegsel, A.T. Effects of dry period length and dietary energy source on metabolic status and hepatic gene expression of dairy cows in early lactation. J. Dairy Sci. 2015, 98, 1033-1045. [CrossRef]

8. Chen, J.; Remmelink, G.; Gross, J.J.; Bruckmaier, R.; Kemp, B.; Van Knegsel, A.T. Effects of dry period length and dietary energy source on milk yield, energy balance, and metabolic status of dairy cows over 2 consecutive years: Effects in the second year. J. Dairy Sci. 2016, 99, 4826-4838. [CrossRef]

9. Van Hoeij, R.; Dijkstra, J.; Bruckmaier, R.; Gross, J.J.; Lam, T.; Remmelink, G.; Kemp, B.; Van Knegsel, A.; Van Knegsel, A.T. The effect of dry period length and postpartum level of concentrate on milk production, energy balance, and plasma metabolites of dairy cows across the dry period and in early lactation. J. Dairy Sci. 2017, 100, 5863-5879. [CrossRef]

10. Britt, J.H.; Kittok, R.J.; Harrison, D.S. Ovulation, Estrus and Endocrine Response after GnRH in Early Postpartum Cows. J. Anim. Sci. 1974, 39, 915-919. [CrossRef]

11. Pushpakumara, P.; Gardner, N.; Reynolds, C.; Beever, D.; Wathes, D. Relationships between transition period diet, metabolic parameters and fertility in lactating dairy cows. Theriogenology 2003, 60, 1165-1185. [CrossRef]

12. Butler, W. Nutritional interactions with reproductive performance in dairy cattle. Anim. Reprod. Sci. 2000, 60, 449-457. [CrossRef]

13. Armstrong, D.G.; Gong, J.G.; Webb, R. Interactions between nutrition and ovarian activity in cattle: Physiological, cellular and molecular mechanisms. Reprod. (Camb. Eng.) Suppl. 2003, 61, 403-414. [CrossRef]

14. Lucy, M. Mechanisms linking nutrition and reproduction in postpartum cows. Reprod. (Camb. Eng.) Suppl. 2003, 61, 415-427. [CrossRef]

15. Fouladi-Nashta, A.A.; Gutierrez, C.G.; Gong, J.G.; Garnsworthy, P.; Webb, R. Impact of Dietary Fatty Acids on Oocyte Quality and Development in Lactating Dairy Cows1. Boil. Reprod. 2007, 77, 9-17. [CrossRef]

16. Garnsworthy, P.; Fouladi-Nashta, A.A.; Mann, G.; Sinclair, K.D.; Webb, R. Effect of dietary-induced changes in plasma insulin concentrations during the early post partum period on pregnancy rate in dairy cows. Reproduction 2009, 137, 759-768. [CrossRef]

17. Van Knegsel, A.; Remmelink, G.; Jorjong, S.; Fievez, V.; Kemp, B.; Van Knegsel, A.T. Effect of dry period length and dietary energy source on energy balance, milk yield, and milk composition of dairy cows. J. Dairy Sci. 2014, 97, 1499-1512. [CrossRef]

18. Gutierrez, C.G.; Dobrinski, I.; Smith, T.T.; Suarez, S.S.; Ball, B.A. Development of a long-term bovine granulosa cell culture system: Induction and maintenance of estradiol production, response to follicle- stimulating hormone, and morphological characteristics. Boil. Reprod. 1997, 56, 608-616. [CrossRef]

19. Glister, C.; Tannetta, D.; Groome, N.P.; Knight, P.G. Interactions between follicle-stimulating hormone and growth factors in modulating secretion of steroids and inhibin-related peptides by nonluteinized bovine granulosa cells. Boil. Reprod. 2001, 65, 1020-1028. [CrossRef] 
20. Spicer, L.J.; Alpizar, E.; Echternkamp, S.E. Effects of insulin, insulin-like growth factor I, and gonadotropins on bovine granulosa cell proliferation, progesterone production, estradiol production, and(or) insulin-like growth factor I production in vitro1. J. Anim. Sci. 1993, 71, 1232-1241. [CrossRef]

21. Spicer, L.J.; Stewart, R.E. Interactions among basic fibroblast growth factor, epidermal growth factor, insulin, and insulin-like growth factor-I (IGF-I) on cell numbers and steroidogenesis of bovine thecal cells: Role of IGF-I receptors. Boil. Reprod. 1996, 54, 255-263. [CrossRef] [PubMed]

22. Graber, M.; Kohler, S.; Müller, A.; Burgermeister, K.; Kaufmann, T.; Bruckmaier, R.; Van Dorland, H. Identification of plasma and hepatic parameters related to metabolic robustness in dairy cows. J. Anim. Physiol. Anim. Nutr. 2011, 96,75-84. [CrossRef] [PubMed]

23. Van Hoeij, R.; Dijkstra, J.; Bruckmaier, R.; Gross, J.J.; Lam, T.; Remmelink, G.; Kemp, B.; Van Knegsel, A. Consequences of dietary energy source and energy level on energy balance, lactogenic hormones, and lactation curve characteristics of cows after a short or omitted dry period. J. Dairy Sci. 2017, 100, 8544-8564. [CrossRef] [PubMed]

24. De Feu, M.; Evans, A.; Lonergan, P.; Butler, S. The effect of dry period duration and dietary energy density on milk production, bioenergetic status, and postpartum ovarian function in Holstein-Friesian dairy cows. J. Dairy Sci. 2009, 92, 6011-6022. [CrossRef] [PubMed]

25. Lucy, M.; Staples, C.R.; Thatcher, W.W.; Erickson, P.; Cleale, R.M.; Firkins, J.L.; Clark, J.H.; Murphy, M.R.; Brodie, B.O. Influence of diet composition, dry-matter intake, milk production and energy balance on time of post-partum ovulation and fertility in dairy cows. Anim. Sci. 1992, 54, 323-331. [CrossRef]

26. Darwash, A.O.; Lamming, G.E.; Wooliams, J.A. The phenotypic association between the interval to post-partum ovulation and traditional measures of fertility in dairy cattle. Anim. Sci. 1997, 65, 9-16. [CrossRef]

27. Galvão, K.; Frajblat, M.; Butler, W.; Brittin, S.; Guard, C.; Gilbert, R.; Gilbert, R. Effect of Early Postpartum Ovulation on Fertility in Dairy Cows. Reprod. Domest. Anim. 2009, 45, 207-211. [CrossRef]

28. Butler, W.; Smith, R. Interrelationships Between Energy Balance and Postpartum Reproductive Function in Dairy Cattle. J. Dairy Sci. 1989, 72, 767-783. [CrossRef]

29. Smith, M.C.A.; Wallace, J.M. Influence of early post partum ovulation on the re-establishment of pregnancy in multiparous and primiparous dairy cattle. Reprod. Fertil. Dev. 1998, 10, 207-216. [CrossRef]

30. Shrestha, H.K.; Nakao, T.; Suzuki, T.; Higaki, T.; Akita, M. Effects of abnormal ovarian cycles during pre-service period postpartum on subsequent reproductive performance of high-producing Holstein cows. Theriogenology 2004, 61, 1559-1571. [CrossRef]

31. Lamming, G.E.; Darwash, A.O. The use of milk progesterone profiles to characterise components of subfertility in milked dairy cows. Anim. Reprod. Sci. 1998, 52, 175-190. [CrossRef]

32. Royal, M.; Mann, G.; Flint, A. Strategies for Reversing the Trend Towards Subfertility in Dairy Cattle. Veter. J. 2000, 160, 53-60. [CrossRef] [PubMed]

33. Kaneko, K.; Kawakami, S. The roles of PGF2 $\alpha$ and PGE2 in regression of the corpus luteum after intrauterine infusion of Arcanobacterium pyogenes in cows. Theriogenology 2009, 71, 858-863. [CrossRef] [PubMed]

34. Herath, S.; Fischer, D.P.; Werling, D.; Williams, E.; Lilly, S.T.; Dobson, H.; Bryant, C.E.; Sheldon, I.M. Expression and function of Toll-like receptor 4 in the endometrial cells of the uterus. Endocrinology 2005, 147, 562-570. [CrossRef] [PubMed]

35. Opsomer, G.; Gröhn, Y.T.; Hertl, J.; Coryn, M.; Deluyker, H.; De Kruif, A. Risk factors for post partum ovarian dysfunction in high producing dairy cows in Belgium: A field study. Theriogenology 2000, 53, 841-857. [CrossRef]

36. Ranasinghe, R.; Nakao, T.; Yamada, K.; Koike, K.; Hayashi, A.; Dematawewa, C. Characteristics of prolonged luteal phase identified by milk progesterone concentrations and its effects on reproductive performance in Holstein cows. J. Dairy Sci. 2011, 94, 116-127. [CrossRef]

37. Mateus, L.; Lopes-Da-Costa, L.; Diniz, P.; Ziecik, A.J. Relationship between endotoxin and prostaglandin (PGE2 and PGFM) concentrations and ovarian function in dairy cows with puerperal endometritis. Anim. Reprod. Sci. 2003, 76, 143-154. [CrossRef]

38. Opsomer, G.; Coryn, M.; Deluyker, H.; Kruif, A. An Analysis of Ovarian Dysfunction in High Yielding Dairy Cows After Calving Based on Progesterone Profiles. Reprod. Domest. Anim. 1998, 33, 193-204. [CrossRef]

39. Kafi, M.; Mirzaei, A.; Tamadon, A.; Saeb, M. Factors affecting the occurrence of postpartum prolonged luteal activity in clinically healthy high-producing dairy cows. Theriogenology 2012, 77, 421-429. [CrossRef] 
40. Harrison, D.S. Reproduction, Milk Production and Culling in Dairy Cows Inseminated at First Estrus after 40 or 60 Days Postpartum. Master's Thesis, Michigan State University. Department of Dairy Science, East Lansing, MI, USA, 1975.

41. González-Recio, O.; Alenda, R. Genetic Parameters for Female Fertility Traits and a Fertility Index in Spanish Dairy Cattle. J. Dairy Sci. 2005, 88, 3282-3289. [CrossRef]

42. Gautam, G.; Nakao, T.; Yamada, K.; Yoshida, C. Defining delayed resumption of ovarian activity postpartum and its impact on subsequent reproductive performance in Holstein cows. Theriogenology 2010, 73, 180-189. [CrossRef] [PubMed]

43. Lucy, M. Regulation of Ovarian Follicular Growth by Somatotropin and Insulin-Like Growth Factors in Cattle. J. Dairy Sci. 2000, 83, 1635-1647. [CrossRef]

44. Beam, S.W.; Butler, W. Effects of energy balance on follicular development and first ovulation in postpartum dairy cows. J. Reprod. Fertil. Suppl. 1999, 54, 411-424. [CrossRef] [PubMed]

45. Gutierrez, C.; Gong, J.; Bramley, T.; Webb, R. Effects of genetic selection for milk yield on metabolic hormones and follicular development in postpartum dairy cattle. J. Reprod. Fertil. Abst. Ser. 1999, 24, 32-36.

46. Garverick, H.A.; Harris, M.; Vogel-Bluel, R.; Sampson, J.; Bader, J.; Lamberson, W.; Spain, J.; Lucy, M.; Youngquist, R. Concentrations of nonesterified fatty acids and glucose in blood of periparturient dairy cows are indicative of pregnancy success at first insemination. J. Dairy Sci. 2013, 96, 181-188. [CrossRef]

47. Huszenicza, G.; Jánosi, S.; Kulcsár, M.; Kóródi, P.; Reiczigel, J.; Kátai, L.; Peters, A.; De Rensis, F. Effects of Clinical Mastitis on Ovarian Function in Post-partum Dairy Cows. Reprod. Domest. Anim. 2005, 40, 199-204. [CrossRef]

48. Petersson, K.-J.; Strandberg, E.; Gustafsson, H.; Berglund, B. Environmental effects on progesterone profile measures of dairy cow fertility. Anim. Reprod. Sci. 2006, 91, 201-214. [CrossRef]

49. Jorritsma, R.; Wensing, T.; Kruip, T.A.; Vos, P.L.; Noordhuizen, J.P. Metabolic changes in early lactation and impaired reproductive performance in dairy cows. Veter. Res. 2003, 34, 11-26. [CrossRef]

50. Rutter, S.; Jackson, D.; Johnson, C.; Forbes, J. Automatically recorded competitive feeding behaviour as a measure of social dominance in dairy cows. Appl. Anim. Behav. Sci. 1987, 17, 41-50. [CrossRef]

51. Ospina, P.; Nydam, D.; Stokol, T.; Overton, T. Associations of elevated nonesterified fatty acids and $\beta$-hydroxybutyrate concentrations with early lactation reproductive performance and milk production in transition dairy cattle in the northeastern United States. J. Dairy Sci. 2010, 93, 1596-1603. [CrossRef]

52. Ospina, P.; Nydam, D.; Stokol, T.; Overton, T. Association between the proportion of sampled transition cows with increased nonesterified fatty acids and $\beta$-hydroxybutyrate and disease incidence, pregnancy rate, and milk production at the herd level. J. Dairy Sci. 2010, 93, 3595-3601. [CrossRef] [PubMed]

53. Mihandoost, B.; Mogheiseh, A.; Nazifi, S.; Ahmadi, M.R.; Ansari-Lari, M. Metabolic status and ultrasound traits of reproductive tract of estrus dairy cows in early postpartum period. Comp. Haematol. Int. 2019, 28, 689-693. [CrossRef]

54. Lucy, M.; Staples, C.; Michel, F.; Thatcher, W.; Bolt, D. Effect of Feeding Calcium Soaps to Early Postpartum Dairy Cows on Plasma Prostaglandin F2 $\alpha$, Luteinizing Hormone, and Follicular Growth. J. Dairy Sci. 1991, 74, 483-489. [CrossRef]

55. Keskin, A.; Mecitoğlu, G.; Bilen, E.; Güner, B.; Orman, A.; Okut, H.; Gumen, A. The effect of ovulatory follicle size at the time of insemination onpregnancy rate in lactating dairy cows. Turk. J. Veter. Anim. Sci. 2016, 40, 68-74. [CrossRef]

56. Adamiak, S.; Mackie, K.; Watt, R.; Webb, R.; Sinclair, K.D. Impact of Nutrition on Oocyte Quality: Cumulative Effects of Body Composition and Diet Leading to Hyperinsulinemia in Cattle1. Boil. Reprod. 2005, 73, 918-926. [CrossRef]

57. Adamiak, S.J.; Powell, K.; Rooke, J.A.; Webb, R.; Sinclair, K.D. Body composition, dietary carbohydrates and fatty acids determine post-fertilisation development of bovine oocytes in vitro. Reproduction 2006, 131, 247-258. [CrossRef]

58. Fouladi-Nashta, A.A.; Campbell, K.H.S. Dissociation of oocyte nuclear and cytoplasmic maturation by the addition of insulin in cultured bovine antral follicles. Reproduction 2006, 131, 449-460. [CrossRef]

(C) 2020 by the authors. Licensee MDPI, Basel, Switzerland. This article is an open access article distributed under the terms and conditions of the Creative Commons Attribution (CC BY) license (http://creativecommons.org/licenses/by/4.0/). 